\title{
The Depiction of the Arsacid Dynasty in Medieval Armenian Historiography
}

\section{Introduction}

The Arsacid, or Parthian, dynasty was founded in the 250s BCE, detaching large territories from the Seleucid Kingdom which had been formed after the conquests of Alexander the Great. This dynasty ruled Persia for about half a millennium, until 226 CE, when Ardashir the Sasanian removed them from power. Under the Arsacid dynasty, Persia became Rome's main rival in the East. Arsacid kings set up their relatives in positions of power in neighbouring states, thus making them allies. After the fall of the Artaxiad dynasty in Armenia in 66 CE, Vologases I of Parthia, in agreement with the Roman Empire and the Armenian royal court, proclaimed his brother Tiridates king of Armenia. His dynasty ruled Armenia until 428 CE. Armenian historiographical sources, beginning in the fifth century, always reserved a special place for that dynasty.

Movsēs Xorenac 'i (Moses of Xoren), the 'Father of Armenian historiography,' attributed the origin of the Arsacids to the Artaxiad kings who had ruled Armenia beforehand. Early Armenian historiographic sources provide us with a number of testimonies regarding various representatives of the Arsacid dynasty and their role in the spread of Christianity in Armenia. In Armenian, as well as in some Syriac historical works, the origin of the Arsacids is related to King Abgar V of Edessa, known as the first king to officially adopt Christianity. Armenian and Byzantine historiographical sources associate the adoption of Christianity as the state religion in Armenia with the Arsacid King Tiridates III.

Gregory the Illuminator, who played a major role in the adoption of Christianity as Armenia's state religion and who even became widely known as the founder of the Armenian Church, belongs to another branch of the same family. Medieval Armenian sources call that branch of the Arsacids, which played a significant role in the middle of the fifth century, the Pahlavuni branch. It produced a series of catholicoi who presided over the Armenian Church until the line was broken by Sahak I 'The Parthian' (386-428?). A number of medieval catholicoi, particularly from Gregory II Vkayaser to Gregory VI Apirat (eleventh-twelfth centuries), also descended from the Pahlavuni family. A theoretical justification of this inheritance was elaborated in the eleventh century and, especially, in the Vipasanut iwn (Narratio) of Catholicos Nerses IV the Gracious (twelfth century).

From an early period, Roman and Byzantine authors speak of the Parthian Arsacids as the ruling dynasties both in Persia and Armenia. Some scions of the Arsacid dynasty, who were mostly associated with the Byzantine Empire, are mentioned in 
Procopius of Caesarea's History. Apocalyptic works preserved in Greek and attributed to the Catholicos Sahak I attach great importance to the Arsacid dynasty in the future restoration of Armenian kingship. A number of apocalyptic works preserved in Armenian are also associated with this family. The earliest source attributed to Catholicos Sahak is incorporated into the historical work of Łazar P'arpec ${ }^{\circ}$ (fifth century). ${ }^{1}$ In the ninth and tenth centuries, Emperor Basil I the Macedonian was said to have Arsacid origin by Patriarch of Constantinople Photios and by Basil's grandson Constantine VII Porphyrogennetos.

These and other sources allow us to seek common roots of the Armenian and Byzantine claims regarding the Arsacids. They found fertile ground both in Armenian and Byzantine historiographical traditions, shaping the image of the Arsacids as good Christian rulers.

\section{On the Subject of the Arsacids}

The royal house of the Arsacids or Parthians first appeared in history around 250 BCE when it seceded from the Seleucid Hellenistic state formed in the aftermath of Alexander the Great's campaigns. The Parthian-Arsacid dynasty ruled over Iran for about 500 years until 226 CE when Ardashir the Sasanian, founder of a new dynasty, deprived them of their power. ${ }^{2}$

However, little is known about the rule of members of the Parthian-Arsacid royal family or their attitude towards their kingdom. We know that the Arsacids considered their power as divine gift; they founded a new temple in Iran on the occasion of the coronation of each of their new rulers and thereby sanctified each monarch's rule. ${ }^{3}$ Moreover, in conformity with ancient conventions, they traced their dynasty back to the Achaemenids, constructing their direct descent from Artaxerxes II. ${ }^{4}$ Thus, follow-

1 See G. Muradyan, The Vision of St. Sahak in the History of Łazar P'arpec 'i. The Armenian Apocalyptic Tradition. A Comparative Perspective. In: Kevork B. Bardakjian and Sergio La Porta (eds.), Essays Presented in Honor of Professor Robert W. Thomson on the Occasion of His Eightieth Birthday, Leiden, Boston, 2014, 313-325.

2 V. G. Lukonin, Iran in Ancient Times and the Early Middle Ages [Essay on the History of Culture], Moscow, 1987 (in Russian: В.Г. Луконин, Древнийи ранне-средневековый Иран (Очерки истории культуры), Москва, 1987), 87-88.

3 Lukonin (cf. fn. 2) 109, 115; M.R. Shayegan, Arsacids and Sasanians. Political Ideology in Post-Hellenistic and Late Antique Persia, Cambridge, New York, 2011, 137-150, 226-228.

4 Arrianus, Flavii Arriani quae extant omnia, ed. by A.G. Roos, vol. II: Scripta minora et fragmenta / Editio stereotypa correctior addenda et corrigenda adecit G. Wirth, Leipzig, 1968 [Bibliotheca scriptorum graecorum et romanoeum Teubneriana], 225; Lukonin (cf. fn. 2) 109, 116; Cf. also A. Pétrovitch, Arsacid Coins, Part I: Collections of the Knight Alexander Pétrovitch. A Brief History of the ParthoArmenians by Jacobos, archbishop of Tashean, Vienna, 1917 [Bibliothèque Nationale, LXXX.] (in Ar-

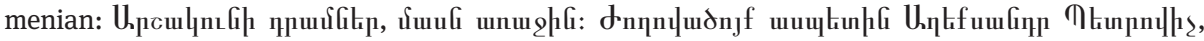

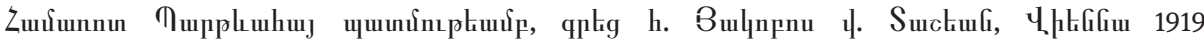

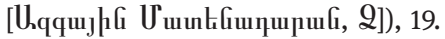


ing ancient historiography, King Sohemos who seized power twice in Armenia in the second century CE, was a member of both the Achaemenid and Arsacid royal houses (his origins are cited below). ${ }^{5}$

The aforementioned conception of royal power was adopted by the succeeding Sasanian dynasty, ${ }^{6}$ which attempted to create the illusion of a continuity of their power in Iran, starting with the time of Cyrus the Great (about 600-530 BCE) and persisting until the end of the seventh century CE when the Arabs deposed the last Sasanian Kings. According to the seventh-century Byzantine historian Theophylact Simocatta, the Arsacids occupied one of the most important courtly positions during this critical time for the Iranian state. According to Simocatta, it was the Arsacids alone who had the right of royal power in Iran and therefore could crown the Sasanians. ${ }^{7}$ Simocatta also said that Bahram Chobin, ${ }^{8}$ commandant of the Sasanian court and usurper, was a member of this dynasty. ${ }^{9}$ The Arsacid kings often placed their parents (representatives of their dynasty) on the thrones of neighbouring vassal or confederate countries (e.g., Armenia, Georgia, Atropatene, Media, Adiabene, Edessa etc.). ${ }^{10}$

\section{The Arsacids in the Caucasian Historiographical Tradition}

The Arsacid dynasty was founded after the downfall of the Artaxiad dynasty (according to modern historiography) in Armenia during the second half of the first century CE by the Parthian (Arsacid) Vologases I (r. 51-78) with the consent of the Roman Empire and the Armenian court. Vologases proclaimed his brother Tiridates king and the dynasty founded by the latter reigned over Armenia until 428. Medieval Armenian historiography and Movsēs Xorenac'i point towards another view on the es-

\footnotetext{
5 J. Marquart, Untersuchungen zur Geschichte von Eran, in: Philologus. Zeitschrift für das Classische Altertum, Supplementband X, 1, Leipzig, 1905, 222-223; Cf. N. Adontz, Works in Five Volumes, I-V,

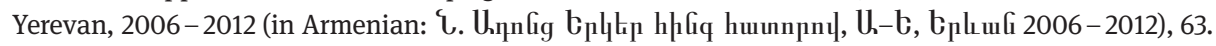
6 Lukonin (cf. fn. 2) 109, 116; Shayegan (cf. fn. 3) 340-368.

7 Thphyl., 3.18.8; 10 (Theophylacti Simocattae Historiae, ed. by C. de Boor, Lipsiae, 1968, 148); Cf. Theophylactus Simocatta History / Russian translation by S.P. Kondratev, Moscou, 1957 (in Russian: Феофилакт Симокатта, История / Пер. С.П. Кондратева, Москва), 94; Cf. E. Sh. Khurshudian, State Institutions of Parthian and Sassanian Iran, III BCE- VII CE, Almaty, 2015 (in Russian: Э.Ш. Хypшудян, Государственные Институты парфянского и сасанидского Ирана. III в. до н.э. - VII в. н.э., Алматы 2015), 161, $200-201$.

8 Cf. A. Sh. Shahbazi, Bahram VI Čōbīn, in: Encyclopaedia Iranica, III/5, 1988, 514-522.

9 Ibid.

10 Lukonin (cf. fn. 2) 118, 120, 135-137.
} 
tablishment of the Arsacid dynasty in Armenia. ${ }^{11}$ In Xorenac i's History of Armenia, the Arsacid dynasty begins around the middle of the second century BCE (nearly two hundred years before the date acknowledged in modern historiography) when Arsaces II, the Arsacid king of Iran, established his brother Vologases on the throne (around 150-140 всE). Similar to Movsēs Xorenac 'i, Sebeos (seventh century) attests to the fact that the kings that held power in Armenia from the beginning of the second century всE are considered as the representative of the Arsacid dynasty. ${ }^{12}$ Likewise, as in Movsēs Xorenac 'i, Tigranes the Great is referred to as an Arsacid king in the works of Faustus of Byzantium and Pseudo-Epiphanius of Cyprus (surviving in Armenian), whereas modern historiography considers him king of the Artaxiad (Artašesyan) dynasty. ${ }^{13}$ It should be noted that Flavius Josephus, the Jewish historian, refers to Artavazd, the son of Tigranes who was captured in 35/34 BCE by the Roman commander Marc Antony and offered to Cleopatra the Great, as "Parthian," that is Arsacid. ${ }^{14}$

That is to say, Movsēs Xorenac $i$, like the whole Armenian medieval historiography, did not recognise the Artaxiad dynasty. Georgian medieval historiography like the Armenian tradition considered the Armenian kings, who were contemporaries of the Seleucids, as Arsacids kings. ${ }^{15}$ In the History of Georgia (K'art'lis c'xovreba), the origins of the sixth Georgian King Arshak are ascribed to the families of the Ne-

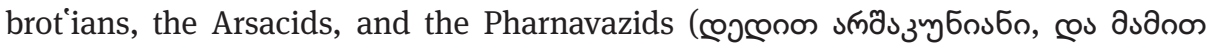

11 N. Garsoïan, L'Histoire attribuée à Movsēs Xorenac'i que reste-t-il à en dire?, in: Revue des études arméniennes 29, 2003, 29 - 48; Id., Movsēs Xorenac i, in: Encyclopaedia Iranica, online: http://www. iranicaonline.org/articles/movses-xorenaci.

12 History of Sebeos, ed. G.V. Abgaryan, Yerevan, 1979 (in Armenian: Muunúnıphıf Utiptnup,

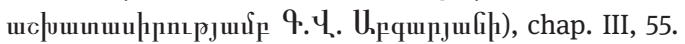

13 Faustus, History of Armenia in Four Parts, Venice, $1933^{4}$ (in Armenian: $\phi_{\text {uutuunul }}$

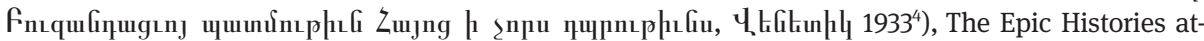
tributed to P'awstos Buzand (Buzandaran Pamut'iwnk'), trans. and comm. by N.G. Garsoïan, Cambridge, 1989, IV, chap. 55; H. Ł. v. Alishan, History of Armenia. The Historians and their Histories, Ven-

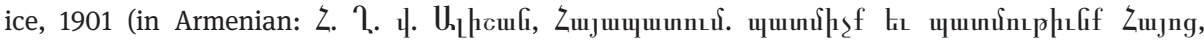
Y.tefitun|l 1901), 31; Cf. Pseudo-Epiphanius, Homilies, ed. by H. Qyoseyan, Etcmiadzin, 2013 (in Ar-

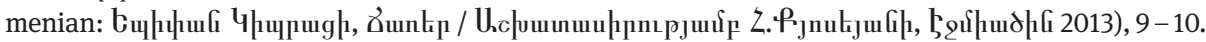
14 Jos., BI 18.5 (Flavius Josephus, Bellum Judaicum, trans. by H. St. J. Thackeray, London, 1956, 170/ 171); Cf. Pétrovitch (cf. fn. 4) 162.

15 L. Mélikset-Bek, Georgian Sources on Armenia and the Armenians, vol. I-II, Yerevan, 1934-1936

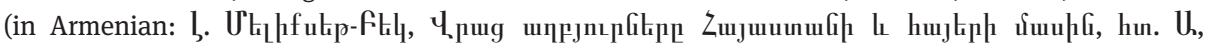
bplıuf 1934, hu. F, 1936), 151, 153, 162; G. A. Melikishvili, Towards the History of Ancient Georgia, Tbilisi, 1959 (in Russian: Г.А. Мелкишвили, К истории древней Грузии, Тбилиси 1959), 49; K’art'lis c'xovreba, ed. by I. Abuladzé (Armenian Translation. The Ancient Armenian Translation of K’art'lis c'xovreba, Georgian Text and the Ancient Armenian Translation), Tbilisi, 1953, 43 (in Armenian

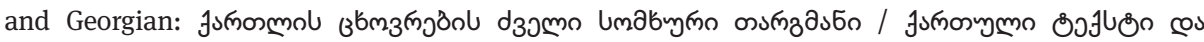

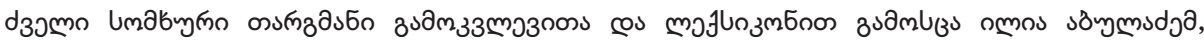
oठ̀ngoun 1953); trans. by R. W. Thompson, Rewriting Caucasian History. The Medieval Armenian Adaptation of the Georgian Chronicles (The Original Georgian Text and the Armenian Adaptation), Oxford, 1996, 43 (the edition was not available to me). 
бృठmmos brot ian and Pharnavazid). ${ }^{16}$ Moreover, according to the Georgian medieval historiographical tradition, certain Georgian kings between the second and first century BCE were also scions of the Arsacid royal house. ${ }^{17}$ Information relating to the history of Armenia in the History of Georgia is denoted with a particular Armenian name: Patmot in "З১ठ20mon6" (in this history a common dialectal form of the Armenians of Tbilisi is preserved until today). ${ }^{18}$ This implies an Armenian origin of the work. ${ }^{19}$

Beginning with the fifth century, Armenian historiography displays a particular attitude towards the royal house of the Arsacids. Movsēs Xorenac i's History of Armenia occupies a special position amongst the works preserved until today in terms of the richness of its description of the Arsacid epoch. It is composed of three parts, and the exposition follows a chronological structure defined by the author. The work represents the entirety of documents compiled by the historian and the logical presentation of events based on these documents. This work leans on historiographical and geopolitical analysis of written sources, oral traditions, and archaeological material accessible to the author. As N. Adontz remarked in his time, the tradition of constructing the descent of the Armenian dynasty from the Arsacids existed in Armenian historiography before Xorenac 'i, which we know from Procopius of Caesarea's De Ae-

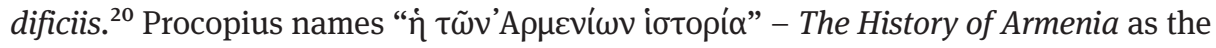
source of his considerations.

The first book of Xorenac 'i's history contains a genealogy of the Armenian dynasty's ancestors beginning with the Patriarch Noah until the establishment of the Arsacids in Iran and Armenia. It should be noted that Xorenac i refers to the History of Mar Abas Catina as his principal source in his presentation of the history of Ancient Armenia. ${ }^{21}$ According to the historian Movsēs, this work was created on the

16 Cf. K'art'lis c'xovreba, ed. by S. Qauxč išvili, t. I et II, Tbilisi, 1955-1959 (in Georgian: Jumonmol उ

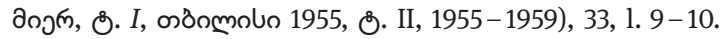

17 Cf. G. A. Melikishvili, Towards the History of Ancient Georgia, Tbilisi, 1959 (in Russian: Г.А. Мелкишвили, К истории древней Грузии, Тбилиси 1959), 49.

18 Mélikset-Bek (cf. fn. 15) 72-73 et passim.

19 Cf. A. Abdaladze "K'art'lis c'xovreba" and the Georgian-Armenian Relations. From Ancient Times Until the Beginning of the Twelvth Century, Tbilisi, 1982 (in Georgian: spm. sठdoususdo, "Jumosmol

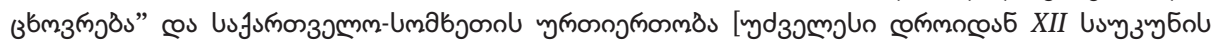

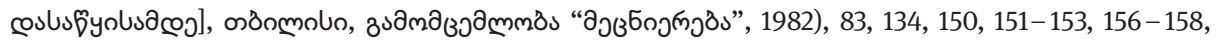
162, 174-176, 216.

20 Procop., aed. 3.1.6, (Procopii Caesarensis opera omnia, ed. by G. Wirth, vol. IV, Leipzig, 1913; reprint 1963); Cf. Adontz (cf. fn. 5) II, 280.

21 G. Khalatiants, The Armenian Epic in the History of Armenian of Moses of Xoren, Moscow, 1896 (in Russian: Г. Халатянц, Армянский эпос в истории Армении Моисея Хоренского, Москва 1896), 9-19, 61-85; G. Khalatiants, The Armenian Arsacids in the History of Armenian of Moses of Xoren, Moscow, 1903 (in Russian: Г. Халатянц, Армянские Аршакиды в “Истории Армении” Моисея Хоренского, ч. І. Исследование, ч.ІІ. Материалы, Москва 1903), 5 ff.; N. Adontz, Armenia 
basis of documents from the royal Persian (Iranian) archives under the patronage of Vologases, the first king of Armenia (second-first century BCE). A majority of researchers (N. Adontz, ${ }^{22}$ H. Manandian ${ }^{23}$ ) agree that the History of Maraba Mcurnac i conserved in the two first chapters of the History of Sebeos is identical with Mar Abas Catina's work as mentioned by Xorenac 'i. The Syriac Garshuni Chronicle by Maribas the Chaldean should be taken into consideration in the same way. ${ }^{24}$ A complete analysis of the genealogical lists of Movsēs Xorenac $i$, Sebeos and Maribas can open new ways of research upon these works, as well as reveal so far unknown historical-philological connections in the Armenian-Syrian world.

The historical genre as used by Xorenac i is closely linked to biblical genealogy. In this aspect, Xorenac'i takes up the example of Eusebius of Caesarea's Chronicle. The line of the first Armenian Patriarchs begins with Hayk, the eponymous ancestor of the Armenians (Hayk ${ }^{e}$ ), and ends with Tigranes, contemporary of King Ajdahak of Marastan (that is Media), who lived before the campaigns of Alexander the Great. Xorenac $i$ outlines the line of patriarchs and kings previously in power back to Togarmah/Togarmas, scion of Japheth, who was the son of the Patriarch Noah. The main feature of this way of presentation was transmitted in Armenian historiography, where it served in certain cases as an example for the historical works of Leonti Mroveli (ninth century) and parts of it were included in the Kart lis c'xovreba (The Life of Georgia), which is one of the most ancient works in Georgian historiography. ${ }^{25}$

Based on sources known to him, Movsēs Xorenac' $i$, the founder of Armenian historiography, attributes an Arsacid origin to the kings who ruled Armenia after the campaigns of Alexander the Great and parallel to the epoch of the Seleucids. According to Xorenac $i$, around 150 - 140 BCE King Arsaces the Brave of Parthia, after revolting against the Seleucids, and chasing them away from his territory, established his brother Vologases as heir to the throne of Armenia. ${ }^{26}$

Xorenac $i$ connects the reigns of Persian kings to those of Armenian kings by setting up chronologically concordant lists based on self-made tables. As one might expect, the historian often mentions Roman emperors as well as persons and events

in the period of Justinian. The Political conditions based on the Naxarar System, trans. with partial revisions, a bibliographical note, and appendix by Mina G. Garssoïan, Lisbon, 1970, 196.

22 N. Adontz, The Initial History of Armenia, Tiflis, 1899 (in Russian: Начальная история Армении у Себеоса в ея отношениях к трудам Моисея Хоренского и Фауста Византийского. - Византийский Временник, т. VIII, вып. 1-2, 1899), 64-105; Adontz (cf. fn. 20) 196.

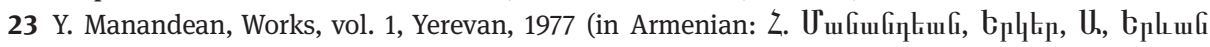
1977), $38 \mathrm{ff}$.

24 Cf. Maribas the Chaldean 1903, Extraits de la Chronique de Maribas Kaldoyo (Mar Abas Catina), Essai de critique historico-littéraire / par Fr. Macler, in: JA, dixième série, t. I, 1903, mai-juin, 491549. Michael the Syrien also cites Maribas the Chaldean among the sources of his History (Ibid., 493). 25 Cf. Mélikset-Bek (cf. fn. 15) 74, 143-147 et passim. It is Adontz who steers the attention of contemporary researchers to this circumstance (Adontz [cf. fn. 5] t. I, 434).

26 The Georgian historiography of the High Middle Ages has also preserved the tradition that Arsaces ascended the Armenian throne, cf. Mélikset-Bek (cf. fn. 15) 74-75, 150-152. 
related to the Arsacid kings. Xorenac $i$ attributes deeds to the Arsacids that modern historiography ascribes to the Artaxiads (second-first century BCE). Apart from the aforementioned account of Flavius Josephus, Graeco-Roman historiography instead provides us with indirect evidence that supports Xorenac i's view. ${ }^{27}$

\section{Movsēs Xorenac 'i and the Arsacids}

It is not new to say that Xorenac i's work revolves around the history of the royal house of the Arsacids. ${ }^{28}$ In the second and third book of his work he introduces the history of the Arsacids until the year 428, which is the date of their fall in Armenia. Thus, the Arsacids reigned in Armenia for over 500 years according to Xorenaci's chronological system. This date passed from the Armenian tradition to the Byzantine historian Procopius of Caesarea. ${ }^{29}$ The chronological line between Xorenaci's second and third book is the adoption of Christianity in Armenia under the reign of Tiridates III, the Arsacid. According to Xorenac i $i$, the Arsacids are descendants of Keturah, the third wife of Abraham, himself a descendant of Sem, the son of Noah. In this general aspect, this genealogy is maintained in Armenian historiography during the following epochs. However, in certain historiographical works of the tenth century, ${ }^{30}$ the Arsacids and likewise the Haykians (the descendants of Hayk', ancestor of the Armenians) are considered descendants of

27 B. Harut unian is right to consider the transmission of the Parthian title "king of kings" to Tigranes the Great and its return to the Arsacid kings of Persia as an argument for this point of view. (Cf. B. Harut unian, La maison princière des Artzrounides dans l'histoire d'Arménie, Yerevan,

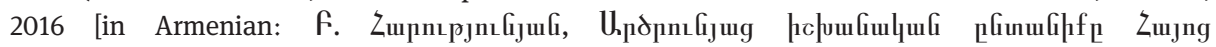

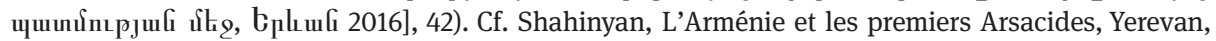

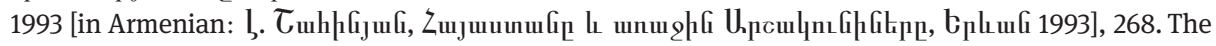
information referring to the identity of King Artavasdes mentioned above by Flavius Josephus points in the same direction.

28 This is what G. Khalatiants, one of the most vehement critics of Movsēs Xorenac ${ }^{\prime} i$, did by calling his book Movsēs of Xoren and the Armenian Arsacids, cf.: G. Khalatiants, The Armenian Arsacids in the History of Armenia of Moses of Xoren, Moscow, 1903 (in Russian: Г. Халатянц, Армянские Аршакиды в “Истории Армении” Моисея Хоренскго, ч. I. Исследование, ч.ІІ. Материалы, Москва 1903).

29 Procop. aed. 3.1.6 (cf. fn. 20); cf. Procopius of Caesarea. Translation, Introduction, and Notes by H. Bartikian (Foreign Sources on Armenia and the Armenians 5, Byzantine Sources, 1), Yerevan, 1967 (in

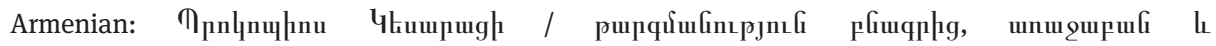

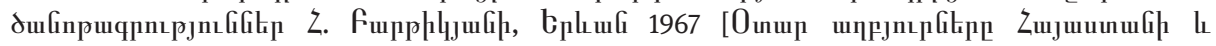

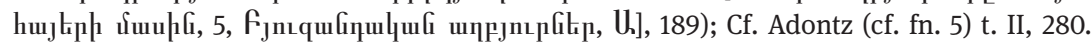

30 Mainly, this is the case with the History of Movsēs Kałankatuac 'i, cf.: Movsēs Kałankatuac'i. History of Albania, Critical Text and Introduction by V. Araqelyan, Yerevan, 1983 (in Armenian: U nulutu

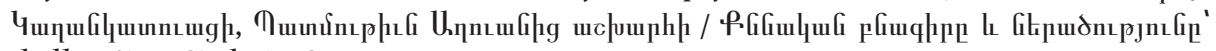

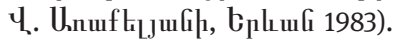


Togarmah/Togarmas. ${ }^{31}$ One of the most important arguments in medieval Armenian and Georgian historiography is the idea that the Haykians as well as the Kart'lossians (according to Leonti Mroveli, Kart'los is the ancestor of the Georgians) are descended from the Patriarch Togarmah/Togarmas. ${ }^{32}$ This argument retraces the initial point for the history of the region to the new beginnings of mankind after the deluge. The Stromates (Bufiuluuuuunnu) attributed to Gregory the Illuminator and one of the oldest works written in Armenian relates that: "In Armenia and in Persia there is no greater power than the one of the house of the Arsacids, who are the descendants of Abraham and at the same time kings of all nations in conformity with the word of the Lord." 33 Deviating from Xorenac $i$, the Stromates does not say that the Arsacids were the progeny of the concubine Keturah. It should be noted that Smbat Davitisdze, the Georgian twelfth-century historian, calls Mariam, the mother of King Bagrat (tenth century), “... the descendant of the magnificent, great and powerful Arsacid kings," even though we know that she was part of the house of Artsruni. ${ }^{34}$ Moreover it should be noted that Dvin and Ani are referred to as Arsacid ${ }^{35}$ estates in fourteenth-century Georgian chronicles. However, Parsadan Gorgijanidze, the seventeenth-century historian, writes that before the Bagratids, "the descendants of the Arsacids ruled over Armenians and Georgians." ${ }^{36}$ This demonstrates that people from the Caucasian region have preserved the memory of the Arsacids for quite some time.

Be that as it may, one can assert that the principal subject of Xorenac i's two final books is the evaluation of the reigns of Arsacid kings on the basis of Christian values. This becomes apparent in his individual evaluation of every house and king of the dynasty. From this point of view, one should look at the very last chapter of Xorenacii's book and his title "Lamentation of the loss of the Armenian throne by the Arsa-

31 One assumption of this genre is preserved in the text mentioned above, which is attributed to Pseudo-Epiphanius or Epiphanius of Cyprus. Cf. Alishan (cf. fn. 13) 31. Cf. as well: Pseudo-Epiphanius, Sermo de Antichristo (Armeniaca de fine temporum), Introducione testo critico, versione latina e note di Giusepe Frasson, Venice, 1976 (Bibliotheca Armeniaca. Textus et Studia, cura academiae armeniacae S. Lazari venetiarum, 2), 18, 1. 145-150.

32 Cf. Mélikset-Bek (cf. fn. 15) t. I, 143 et passim.

33 Gregory the Illuminator, Discourse on the Faith (the Stromates) of Our Father, the Saint and Blessed Gregory the Illuminator, with a Preface, Comparison, and Annotations by A. Ter-Mikélian,

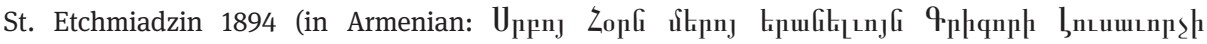

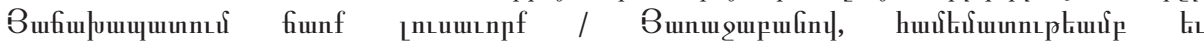

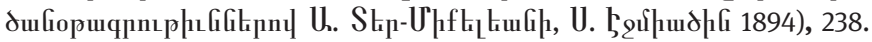

34 Cf. Mélikset-Bek (cf. fn. 14) t. I, 138-139; K’art'lis c'xovreba (cf. fn. 16) t. I, 386, 25-27. Cf. Abdaladze (cf. fn. 19) 216.

35 Cf. Mélikset-Bek (cf. fn. 15) t. II, 54. Cf. K’art'lis c'xovreba (cf. fn. 16) t. II, p. 186, 1. 9.

36 Cf. Mélikset-Bek (cf. fn. 15) t. II, 96; Cf. Abdaladze (cf. fn. 19) 83, 134, 150, 151-153, 156-158, 162, $174-176,216$. 
cid Dynasty and of the archiepiscopate by the family of Gregory the Illuminator." ${ }^{37}$ The general characteristics of this idea developed within Armenian literature were passed on to the work De Aedificiis of Procopius of Caesarea (3.1) in the sixth century. In all likelihood, the work of Procopius is one of the bridges linking Armenian historiography to literary works from the Macedonian epoch, especially with the works about the life and deeds of Basil I. Nevertheless, Procopius's work is no exception in Byzantine literature in respect to the transmission of information on the Arsacids. As we have already seen, Theophylact Simocatta underlines the exceptional role of the Arsacids in Persian political life while talking about the last stage of the Sasanian period. ${ }^{38}$ The French Byzantinist Christian Settipani has recently tried to summarise information on the political activities of different politicians originating from the Armenian Arsacids passed on between the sixth and tenth centuries in Byzantium and to recreate family trees, ${ }^{39}$ taking up the work of Cyrille Toumanoff. ${ }^{40}$

\section{The Christian Virtues of the Arsacids}

The next step in Xorenac 'i's characterisation of the Arsacids within the system of Christian values is to correlate them with the King Agbar of Edessa, who had written a letter to Christ and adopted Christianity. Armenian historiography from the High Middle Ages contains numerous accounts referring to the relation between representatives of the Arsacid dynasty and certain episodes in the propagation of the Christian faith in Armenia. This problem found its solution in the History of Armenia of Movsēs Xorenac $i$ in which the role of intermediary between Abgar and Christ is reserved for the Apostle Thaddeus (or Addai in the Syriac text). This follows the presentation of Eusebius of Caesarea and not the account of Labubna, who was the scribe of King Abgar. Despite knowing Labubna, Xorenac'i followed the general direction of the Ecclesiastical History of Eusebius of Caesarea in his depiction. However, two additions by Xorenac $i$ do not exist in Eusebius of Caesarea: The first claims that Abgar was king of Armenia and the second alleges that he, king of Edessa and contemporary of Christ, was part of the Arsacid dynasty. The second addition is also transmitted to other pieces of Armenian literature whereas the first addition can also be

37 Cf. Movsēs Xorenac i, History of Armenia, ed. by M. Abełyan and S. Harut iwnyan, Tbilisi 1913 (in

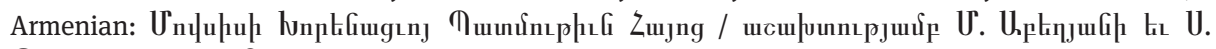

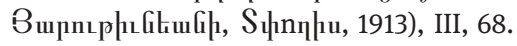

38 Theophylact Simocatta (cf. fn. 7) 147-148, III 18, 6-8.

39 C. Settipani, Continuité des élites à Byzance durant les siècles obscurs. Les princes caucasiens et l'empire des VIe et IXe siècles, Paris, 2006, 106-130.

40 C. Toumanoff, Les dynasties de la Caucase chrétienne de l'Antiquité jusqu'au XIXe siècle. Tables généalogiques et chronologiques, Rome, 1990², 84-91. 
found in a certain number of historiographical works in Syriac. ${ }^{41}$ In addition, the Byzantine world of the Macedonian period did not remain indifferent regarding the relics of King Abgar of Edessa. The portrait created by divine power and sent by Christ himself to Abgar and their correspondence has been considered as guarantee for the inviolability of Edessa. Both were transferred to the Church of the Virgin of Blachernae located in a district of Constantinople in 944 - there they became one of the most important guarantees for the continuity of the power of the Byzantine Emperor. It seems likely to us that the description of this historical event did not occur by chance and had been penned by Constantine VII Porphyrogennetos (although for the emperor of Byzantium King Abgar was neither Armenian nor Arsacid). ${ }^{42}$

In the second and third chapter of his History, Movsēs Xorenac $i$ ascribes different Christian virtues to a certain number of Arsacid kings (both pagan and Christian). For Movsēs Xorenac $i$, the virtues of Arsacid kings are: courage, majesty, fidelity, wisdom, and dedication to Armenia. Among the pagans, it is Vologases (the Valiant, the Sage etc.), ${ }^{43}$ the founder of the Arsacid dynasty who is valued the most; among the Christian kings, it is Tiridates III (the victor, "being resplendent with all virtues") ${ }^{44}$ under whose reign Gregory the Illuminator propagated the new religion in Armenia. According to accounts from Armenian and Byzantine literature, the official adoption of Christianity in Armenia is ascribed to the activities of King Tiridates III the Arsacid. Tiridates, the first Christian king, is also present in the genealogy of the Macedonian King Basil I. Nicolas Adontz supposes that this genealogy was created by Photius (r. 858-867, 877-886), patriarch of Byzantium..$^{45}$ Among the works that have been handed down to us, the biography of Basil I, written by his grandson Constantine

41 Cf. Chronicon Anonimum, Chronicon ad annum Christi 1234 pertinens. I, ed. by J.-B. Chabot, Praemissum est Chronicon Anonymum ad A.D. 819 pertinens. Curante Aphram Barsaum (CSCO 81, Syr. 36), Louvain, 1920, 120 (= Anonymus d'Édesse, Chronicle: Translation, Introduction, and Notes by L. Ter-Petrosyan, Yerevan 1982 [Foreign Sources on Armenia and the Armenians 12, Syriac Sources

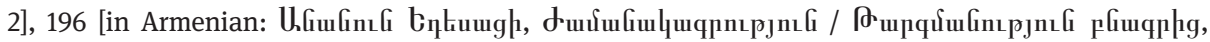

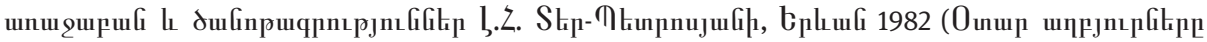

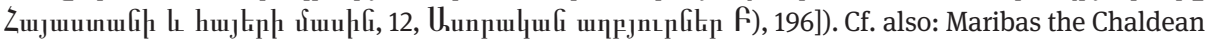
(cf. fn. 24) 534-540.

42 Cf. Constantinus Porphyrogennetos, Narratio diversis ex historiis collecta de divina Christi Dei nostra imagine non manufacta ad Augaium missa (PG, t. 113, col. 423-454); Translation, Introduction, and Notes by H. Bartikian, Constantine Porphyrogennetos, Yerevan, 1970 (Foreign Sources on Armenia and the Armenians 6, Byzantine Sources 2), 177-220 (in Armenian: Ynuunufinpfi

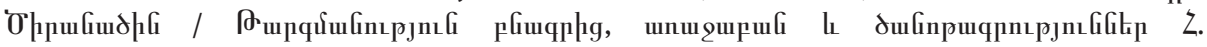

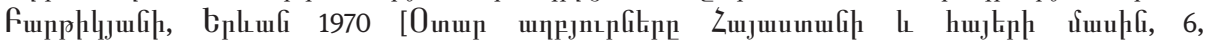

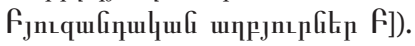

43 Movsēs Xorenac $i$, Moïs de Khorène. Histoire de l’Arménie, Nouvelle traduction de l'arménien classique par Annie et Jean-Pierre Mahé (d'après Victor Langlois) avec une introduction et des notes, Paris, 1993, 117, $119 \mathrm{ff}$.

44 Movsēs Xorenac'i (cf. fn. 37) 229-230, 247-249.

45 Cf. N. Adontz, L'âge et l'origine de l'empereur Basile I., in: BZ 1933/1934, 81-85, reédition in: N. Adontz, Études arméno-byzantines, Lisbon 1965, 47-109. 
VII Porphyrogennetos and preserved in the works of the successor of Theophanes the Confessor, acquires conceptual importance:

Now Emperor Basil - for he is the one whom our work intends to present - hailed from Macedonia, but traced his origins to the nation of the Armenians and his lineage back to the Arsacids: For since the ancient Arsakes, the ruler of the Parthians, had attained great glory and virtue, a law had existed in successive generations, [by virtue of which] the king of the Parthians, Armenians, and even Medes had to be drawn from no other race than that of Arsakes and his descendants. While the aforementioned nations were being governed by this dynasty, it happened that one time when the ruler of the Armenians had left his life, a struggle ensued over the crown and the succession to that realm. (Trans. Ševcenko) ${ }^{46}$

This means Constantine VII Porphyrogennetos traced the first establishment of the Arsacid dynasty within the borders of the Byzantine Empire back to the years of the reign of Emperor Leo I (r. 457-474). Intending to resist the tempting solicitations of the Persians, he gave some land to the Arsacids and set them up in the city of Nicaea in Macedonia. ${ }^{47}$ After the disappearance of the Sasanians from the political scene, their place was occupied by the Arab Caliphate (probably towards the end of the eighth century) - however, the influence of the Arsacids was so strong in Armenia they were also invited to the court of the Arab Caliphs. ${ }^{48}$ According to the continuators of Theophanes "... the Saracens hoped that if they had had the descendants of Arsaces under their dominion, they would have been easily able to gain the Armenian people for their cause because this people loved the ancient Arsaces." ${ }^{49}$ According to Constantine VII Porphyrogennetos the Emperor resettled the Arsacids to avoid this temptation and installed them in the city of Philippi of Macedonia and then af-

46 Theophanus Continuatus, Chronographia 1.2 (Chronographiae quae Theophanis continuati nomine fertur liber quo Vita Basilii Imperatoris amplectur, recensuit Anglice vertit indicibus instruxit

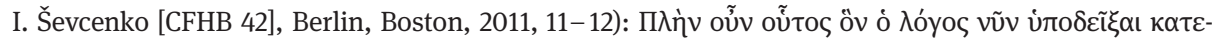

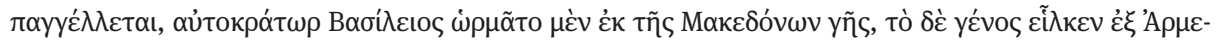

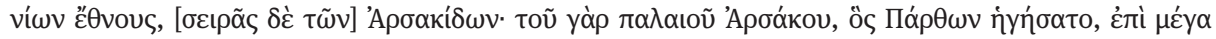

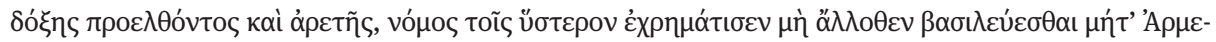

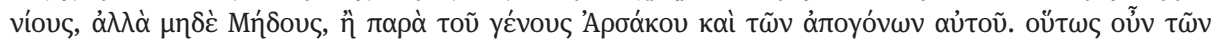

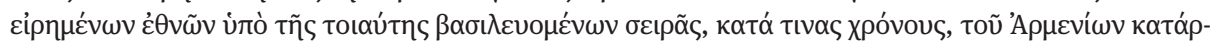

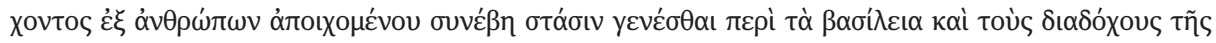

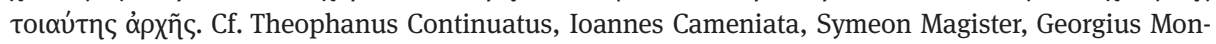
achus, Ex recognitione Immanuelis Bekkeri, Bonnae, 1838, 212-213, I.2; Cf. Continuator of Theophanus, Translation, Introduction, and Notes by H. Bartikian, Yerevan, 1990 [Foreign Sources on Armenia

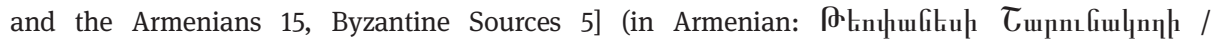

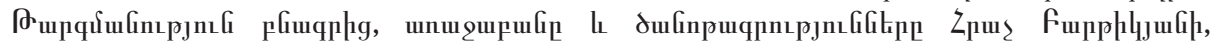

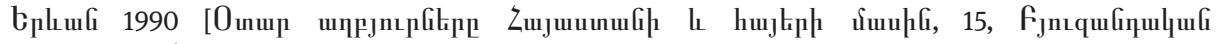
uпрјnцpitip b]).

47 Perhaps this settlement is connected to the revolt led by Vahan Mamikonian, who restored in 484 Armenia's autonomy.

48 Theophanus Continuatus (cf. fn. 46) 14-15, 2.43-45. Cf. Bartikian (cf. fn. 46) 128.

49 Theophanus Continuatus (cf. fn. 46) 14-15, 2.35-38. Cf. Bartikian (cf. fn. 46) 127-128. 
terwards to Adrianople where they managed "to keep their aristocratic origin and national vision pure and unmixed." 50

In his History, Xorenaci $i$ distinguishes between three branches of the Arsacids (the ones of Suren, of Karen, and Ispahbudhan of Parthian-Pahlavi origin). ${ }^{51} \mathrm{He}$ speaks of the confrontation that developed between two branches and which was resolved thanks to Christianity. Gregory the Illuminator, a surviving descendant from the branch of Suren who propagated the faith fighting against the pagans, even baptised Tiridates of Armenia, descendant of the hostile Pahlavi branch. In his medieval history of Armenia, the history of Christianity's propagation by King Tiridates is displayed in multilingual hagiographical works (in Armenian, Greek, Arabic, Syriac and Georgian etc.), as well as in the History of Agat'angełos. It should be noted that the activities of Tiridates III are in many respects aligned to prominent aspects of Constantine the Great's personality. ${ }^{52}$ One of the most important occasions for such a comparison is the treaty concluded between Constantine the Great and Tiridates assisted by bishop Sylvester of Rome and bishop Gregory the Illuminator of Armenia. According to medieval Armenian historiography, the royal power has since been in the hands of the Christian Arsacids, the descendants of Tiridates, and the spiritual power has since been in the hands of Gregory the Illuminator, himself descendant of an Arsacid branch. These two branches of the Arsacid dynasty play an important role in the third book of Movsēs Xorenac'i's History. Gregory the Illuminator was a member of the Surenian branch of the Pahlavi-Arsacid house (this double title of his family branch is used in almost all Armenian medieval sources). Thanks to his efforts the Christian religion was officially adopted in Armenia and he therefore became the famous founder of the Armenian Church. As for the ancestors of the Arsacids, the biographers of Basil I claim descent from both branches (Surenian and Karenian).

Since the time of Gregory, the holders of the title of catholicos have been the pillar of Christianity in Armenia. The fall of the Arsacid dynasty and the abdication of the patriarchal throne by Sahak Partev, who was a descendant and heir to Gregory the Illuminator, were the main reasons Xorenac'i wrote the Lamentation at the end of his History. ${ }^{53}$ For a long time after the fifth century, the echoes of attempts aiming at re-establishing the independence of the Armenian Kingdom were present in medieval visions and within the framework of Christian eschatological literature. ${ }^{54}$ The

50 Theophanus Continuatus (cf. fn. 46) 14, 2.51-53; 16-17, I.3.9-10. Cf. Bartikian (cf. fn. 46 ) 128. 51 On this subject, see Khurshudian (cf. fn. 7) 195-196.

52 In this context, the biographer of Basil I of Macedonia constructs kinship between Basil and Constantine the Great from the maternal side. Cf. Theophanus Continuatus (cf. fn. 45) 16, 3.20. Cf. Bartikian (cf. fn. 46) 129.

53 Cf. Movsēs Xorenac i (cf. fn. 37) 358-366.

54 The first scientific essay in this field was delivered by Achot Hovhannissian in his two-volume monograph Episodes in the History of Armenian Liberation Thought, vol. I, Yerevan, 1957 (in Arme- 
prophecies announcing the return of the Pahlavi-Arsacids played an important role and were also passed on in the biography of Basil I. As Constantine VII Porphyrogennetos says: "It is now that the prediction and prophecy, made 350 years ago by the priest and monk Isaac, himself of Arsacid origin, are fulfilled. He had a vision and thus learned that after this time, one of the descendants of the Arsacids will hold the sceptre of the Roman Empire." 55

\section{The Apocalyptical Role of the Arsacid Dynasty}

In the History of Xorenac $i$, the fall of the Arsacid dynasty was caused by the interruption of the hereditary line of the royal and patriarchal houses of the Arsacids. From this point of view, the Lamentation of Xorenac $i$ is a literary generalisation characterizing the end of the Arsacid epoch. Among the works belonging to this genre, it can be compared to the Lamentations of Jeremiah in the Old Testament. Armenian historiography has attempted to colour the fall of the Arsacid dynasty in an apocalyptical fashion. Movsēs Xorenac'i succeeded in doing exactly that, connecting Armenian historiography with Christian eschatology. After the fifth century, visions attributed to the bearers of the patriarchal title, to the Catholicos Nerses the Great and to Sahak the Parthian (both are members of the Arsacid dynasty and Nerses is Sahak's father) began to circulate equally in Armenian, Byzantine and Georgian literary works. ${ }^{56}$ Already in the History of Faustus of Byzantium the life of Nerses the Great is conceptualised with an eschatological purpose (Faustus of Byzantium, V $24-28) .{ }^{57}$ In the account of the vision of Sahak Part'ev - found in the history of Eazar P'arpec' $i$, dated to the end of the fifth or the beginning of the sixth century as well as in the biography of Basil the Macedonian written by Constantine Porphyr-

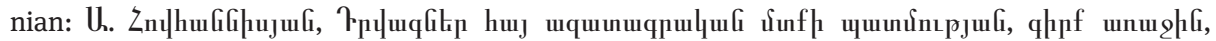
bplıuf 1957).

55 Cf. Theophanus Continuatus (cf. fn. 46) 147-148, 19.35-40. Cf. Bartikian (cf. fn. 46) 143.

56 Cf. Mélikset-Bek, On the Question of the Dating of the Pamphlets of Pseudo-Isaac in Greco-Byzantine Literature, in: VV, vol. VIII, 1956 (in Russian: Л.Мелииксет-Бек, К вопросу о датировке псевдоисааковских памфлетов в греко-византийской литературе. - Византийский Временник, т. VIII, 1956, c. 208-222), 208-222.

57 In the work of Mesrop Vayoc jorec 'i, the tenth-century biographer of Nerses the Great, the catholicos foresees the slipping away of the patriarchal see from the descendants of Gregory the Illuminator, the downfall of the Arsacid dynasty and the appropriation of the True Cross by the Persians before his own death (cf.: Mesrop Vayoc jorec 'i, History of the Catholicos St. Nerses Partev, in: Armenian Writers 11: Tenth Century. Historiography, Antelias, Lebanon, 631-743 [in Armenian: Utupnu

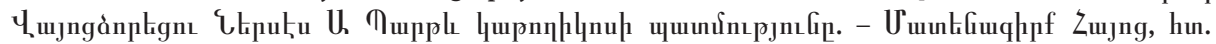

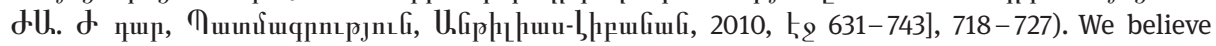
that the following additions are the result of a later redaction of the hagiographical text: "1. Then, the Romans which are called Franks, occupied Jerusalem and took the power away from the Greeks," cf. ibid. 719, 2. "And they deported the Muslims that fell under the unlimited domination of the Romans,” cf. ibid. 720. 
ogennetos - the same 350 years are mentioned, which pass after the prediction of the fall of the royal house of the Arsacids and the patriarchal house of Gregory the Illuminator - at the end of this period the return of this house is foretold (Eazar P'arpec'i, XV). N. Adontz, N. Akinian and A. Hovhannissian and H. Bartikian have pointed to the astonishing resemblance of the accounts given in both works, written in Armenian and Greek. According to one of the most probable hypotheses, the supplement to P'arpec i's work was added at the end of the eighth century on the basis of a source also known to Patriarch Photius. ${ }^{58}$ This prediction is equally known to Arseni Sapareli, the Georgian author of the ninth century. ${ }^{59}$ Nerses Akinian dates the creation of the first text containing the prediction to the eighth century. The Armenian apocalyptical literature is rich and varied and the study of this medieval literary genre remains one of the main problems in Armenology. The manuscripts testifying to the works of this genre are not yet entirely recorded. The eschatological discourse of pseudo-Epiphanius of Salamis testifies to it, treating the question of the loss of Ner (the devil's twin) when the new Tiridates appears in Ani, no longer the capital of the Armenian kingdom but the capital of the Georgian. ${ }^{60}$ Pseudo-Epiphanius refers to Agat'angełos, Xorenac $i$ and Faustus of Byzantium as his sources. ${ }^{61}$

In the apocalyptical works attributed to Sahak and preserved in Greek, he equally ascribes an important role to the Arsacid in restoring the royal power. A certain number of apocalyptical works is bound to the name of this dynasty, of which the most ancient can be found in the historiographical work of P'arpec $i$, which has been attributed to Catholicos Sahak Pahlavuni. The above-mentioned facts allow for a search for the common roots of the Armenian and Byzantine tradition which are closely connected to each other and have found fertile soil in the two medieval

58 Cf. Adontz (cf. fn. 45) 96; N. Akinian, Die Vision des Hl. Sahak I. Eine literar-historische Untersu-

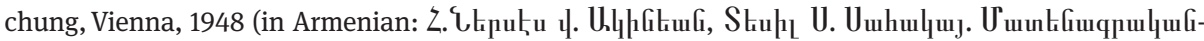

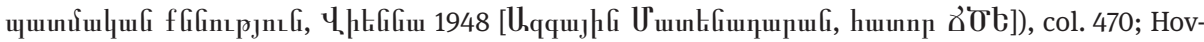
hannissian (cf. fn. 54) I.36-37. Cf. as well M. Shirinyan, Les liens entre l'Histoire de Movsēs Khorénatsi et la Généalogie du patriarche Potus-Achtanak I, Yerevan, 1995 (in Armenian: U. T/p p fijuf,

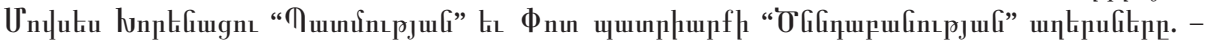
U.cunufuul, U., bplıufi 1995), 85-96.

59 Mélikset-Bek (cf. fn. 15) t. I, 38-39, 57; Cf. Mélikset-Bek, The Georgian "Version" of the "Prophecy" of Sahak Parthev, in: Bulletin of the University of Tibilisi, 2, 1921-1925 (in Georgian: mojm6

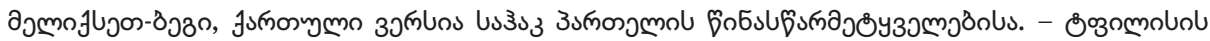

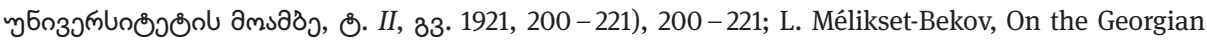
Version of the Apocryphal Vision of Sahak Parthev on the Fate of Armenia. News from the Institute for the Historical Archaeology of Caucasia, vol. II, Leningrad, 1917-1925 (in Russian: Л.МеликсетБек, О грузинской версии апокрифического Видения Саака Парфянина о судьбе Армении. - Известия Кавказского Историко-Археологического Института, Ленинград 1917-1925, с. 164-176), 164-176.

60 Pseudo-Epiphanius (cf. 31) 1976, § 18, 1.145-152, § 20, 1.171, § 22, 1.210, § 40, 1.365-367, 100 -103; Cf. Pseudo-Epiphanius (cf. fn. 13) 752, n. 1.

61 Pseudo-Epiphanius (cf. 31) 20, 1. $170-174$. 
Christian literatures in creating the generous and pro-Christian image of the Arsacids.

According to the Armenian medieval historiographic tradition many of the catholicoi who occupied the patriarchal see of Armenia between the eleventh and twelfth centuries (since Gregory II Martyrophilos until Gregory VI Apirat) emerged from the Pahlavunis. With the objective of restoring national sovereignty (e.g., kingdom), the Armenian princely houses of Cilicia as well as Armenian communities around the world nurtured ideas of enthroning the Arsacids both on the see of the catholicos and the royal throne for a long time. In the nineteenth century, there were attempts to use the example of the Arsacid house to gain political primacy in the years of the Crimean war, ${ }^{62}$ when international politics began to show interest in the Armenian question.

62 From this viewpoint, it is interesting to note that a book published in the nineteenth century carrying the characteristics of Dédéyan of Smyrna starts the genealogy of the royal house of England with the Arsacids (cf. S. M. Vanandetzie, Descent of Her Majesty Victoria Queen of England from the Arsacid Kings of Armenia, Treated by M. Dedeyan, Smyrna, 1866). 
